\title{
Evaluation of the Duration of Peripheral Venous Catheter in Vein in Hospitalized Children
}

\section{Hastaneye Yatan Çocuklarda Periferik Venöz Kateterin Vende Kalma Süresinin Değerlendirilmesi}

\author{
@Mukaddes Demir Acar', @Ümran Çevik Güner1', @Gülçin Yılmaz² \\ 1 Tokat Gaziosmapasa University, Faculty of Health Sciences, Department of Pediatric Nursing, Tokat, Turkey \\ ${ }^{2}$ Tokat Gaziosmapasa University, Health Education and Research Hospital, Pediatri Clinic, Tokat, Turkey
}

\begin{abstract}
Aim: This study was conducted to evaluate the duration of the peripheral venous catheter in vein, which is employed in the treatment of children who are hospitalized in pediatric clinics.

Material and Method: The study was conducted as a prospective and observational-descriptive study. The sampling of the study consisted of the 249 child, who were admitted to the pediatric clinic and who underwent peripheral venous catheter insertion. Institution and ethics committee permission was obtained for the study. The data were collected with the "Peripheral Venous Catheter Monitoring Form" and "Phlebitis Scale", which were prepared according to the literature.

Results: It was determined that a total of $57.8 \%$ of the children who were included in the study were 1-36 months old, $60.6 \%$ were male, and $66.7 \%$ were hospitalized for more than 6 days. It was also determined that the duration of the catheter in children was $58.76 \pm 28$ hours and catheter was inserted $3.61 \pm 1$ times during hospitalization. The negative correlation between "durations of peripheral intravenous catheters in veins" and "number of peripheral intra venous catheters inserted from hospitalization to discharge" was found to be statistically significant. It was determined that $73.5 \%$ of the catheters were removed because of the obstruction.
\end{abstract}

Conclusion: As a result of the present study, it was determined that the peripheral venous catheter in children under three years of age had a shorter duration of remaining in the veins, and children were subjected to repeated peripheral venous catheter attempts because of obstructions before their treatments were completed.

Keywords: Peripheral venous catheter, child, intra venous practice, pediatric clinic, nursing
Öz

Amaç: Bu araştırma, pediatri kliniklerinde yatan çocukların tedavisinde kullanılan periferik venöz kateterin vende kalma süresini değerlendirmek amacıyla yapılmıştır.

Gereç ve Yöntem: Çalışma, prospektif ve gözlemsel-tanımlayıcı olarak yapılmışır. Araştırmanın örneklemini, pediatri kliniğinde yatan ve periferik venöz kateter uygulanan 249 çocuk oluşturmuştur. Araştırma için etik kurul ve kurum izinleri alınmıştır. Veriler, literatüre göre hazırlanmış olan "Periferik Venöz Kateter İzlem Formu" ve "Flebit Ölçeği"ile toplanmıştır.

Bulgular: Araştırma kapsamına alınan çocukların \%57,8'inin 1-36 aylık $\% 60,6$ 'sının erkek ve \%66,7'sinin 6 günden fazla hastanede yattığı belirlenmiştir. Çocuklara uygulanan kateterin vende kalma süresinin $58,76 \pm 28$ saat ve yatı̧ süresince kateter uygulama sayısının ortalama $3,61 \pm 1$ olduğu saptanmıştır. "Periferik venöz kateterin vende kalma süresi" ve "çocuğun yatışından çıkışına kadar takılan kateter sayısı" arasında istatistiksel olarak negatif yönde ilişki olduğu belirlenmiştir $(p<0,05)$. Periferik venöz kateterlerin \%73,5inin tıkanma nedeniyle çıkarıldığı bulunmuştur.

Sonuç: Bu çalışma sonucunda üç yaş altı çocuklarda periferik venöz kateterin vende kalma süresinin daha kısa olduğu ve çocukların henüz tedavileri sonlanmadan özellikle tıkanma nedeniyle tekrarlı periferal venöz kateter girişimlerine maruz kaldıkları bulunmuştur.

Anahtar Kelimeler: Periferik venöz kateter, çocuk, intra venöz uygulama, pediatri kliniği, hemşire

Corresponding (illetişim): Mukaddes Demir Acar, Tokat Gaziosmapasa University, Faculty of Health Sciences, Department of Pediatric Nursing Tokat, Turkey

E-mail (E-posta): mukaddesdemir.acar@gop.edu.tr

Received (Geliş Tarihi): 06.01.2021 Accepted (Kabul Tarihi): 17.04.2021 


\section{INTRODUCTION}

Nowadays, administering fluids, drugs, and electrolytes with peripheral intra venous catheters (PIVC) to veins is a widely used technique. PIVC application is an indispensable element for modern medicine and is the most common invasive intervention at hospitals. ${ }^{[1-4]}$ PIVC are frequently used in cases such as diarrhea and vomiting that can lead to dehydration, in patients to whom liquid electrolytes cannot be given orally, in preoperative and postoperative periods, in continuous or intermittent drug administration, to provide blood and blood products, to ensure total parenteral nutrition, facilitate access to the vein in emergencies, and for hemodynamic monitoring and diagnostic assisting applications. ${ }^{[1,5,6]}$ However, if the treatment period is more than 6 days, it is recommended to use central catheter or peripherally inserted central catheter (PICC) instead of PIVC. ${ }^{[7]}$ In case of clinical indications such as phlebitis, infiltration, obstruction, accidental removal, suspicious infection and completion of therapy, catheters need to be removed or replaced. ${ }^{[4,8]}$ Rickard et al. ${ }^{[9]}$ (2012), in a randomized controlled study, it was determined that there was no additional increase in catheter-related bloodstream infections (CRBSI) compared to the routine replacement of the changed PIVCs in case of clinical indication development. Therefore, PIVCs should not be changed unless clinical indications develop. However, children are subjected to repeated peripheral catheter applications for the completion of unfinished treatments before they recover because of phlebitis, catheter displacement, obstruction, infiltration or even extravasation. ${ }^{[10,11]}$ In addition, since the diameters of the appropriate veins are small and difficult to find in children, recurrent peripheral catheter applications provide the ground for pain, trauma, and infection in children, cause disruption of treatments, create intense anxiety and stress in the family, and causes stress and loss of labor and corporate cost losses in nurses. ${ }^{[1,12]}$ In addition, peripheral catheter applications are a stressful procedure that requires being in close proximity with the patient in clinics of diseases such as covid 19 that are at risk of intensive transmission. ${ }^{[13,14]}$

Safe initiation, execution, and termination of intra venous treatment is a very significant practice for pediatric nurses and requires specialization. Variables such as appropriate dilution of the drugs, the use of the infusion pump, the nature of the area where the PIVC is inserted, the determination of the area, the care of the area, the age of the child and the child's disease, dressing, knowledge and experience of the nurse, may affect the duration of the catheter in the vein and complications. ${ }^{[5,10,15]}$ Prevention of infiltration/extravasation (I/E) in pediatric patients is important. A study has examined the effect of an education program, which aims to prevent and manage pediatric $\mathrm{I} / \mathrm{E}$, on $\mathrm{I} / \mathrm{E}$ rates in pediatric patients. The study has led to an improvement in nursing care, an improvement in the quality of patient care and has helped progress toward increased patient safety. ${ }^{[16]}$ For this reason, the main aim of pediatric nurses in monitoring, maintenance, security and management of infusion must be taking the necessary precautions to increase the duration of the catheters in veins without complications. ${ }^{[17,18]}$ Because, as mentioned before, finding the right vascular pathway is difficult and traumatic in children. On the other hand, atraumatic care is an important concept in nursing literature and is a healthcare philosophy aiming to minimize physical and psychological difficulties for children and their families in healthcare settings. The main target in atraumatic care is not to cause any damage. ${ }^{[19]}$ Most pediatric patients have at least one PIVC insertion during their hospitalisation. Despite the important function of PIVC for delivery of intra venous therapy, failure and complications rates are widely reported; however these results have not been synthesised. PIVC failure and complications in paediatrics patients are a significant problem globally. Therefore, continued efforts from health care providers are required to decrease the incidence of these complications. ${ }^{[15]}$

\section{Purpose of the Study}

This study was conducted for the primary purpose of examining the duration of the PIVC in the vein, the number of PIVC inserted until discharge, and the causes of removals of PIVC, which are used at children hospitalized in pediatric clinics.

\section{Research Questions}

1. What is the duration of the PIVC in the vein and number of times the PIVC was inserted until discharge in pediatric patients?

2. Does the child's age, gender, catheter type and catheterized area of the child affect the duration of the PIVC in the vein and the number of PIVC placed in the child until discharge?

3. Is there a relationship between duration of the PIVC in the vein and the number of PIVC placed in the child until discharge?

4. What are the reasons for removing the PIVC?

\section{MATERIAL AND METHOD}

\section{Study Type}

The study was conducted as a prospective and observationaldescriptive study.

\section{Place and Sampling of the Study}

The universe of the research consists of children treated with PIVC implantation in the pediatric clinic. The sampling of the study consisted of the children $(n=249)$, who were admitted to the pediatric clinic and who underwent peripheral venous catheter insertion. The study was based on the monitoring of children who were treated with peripheral venous catheters in pediatric clinic of a University Hospital in Turkey between January and June 2018. In the pediatrics clinic, patients who need medical treatment of acute and chronic diseases between the ages of 1-18 are hospitalized and there are no surgical patients. The minimum sample size was calculated with the G*Power 3.1.9 program based on the literature. ${ }^{[20]}$ Accordingly, the total number of samples that should be included in the 
study was calculated as $\mathrm{n}=246$ for $80 \%$ statistical power, 0.16 effect size and 0.05 type 1 error. The research was completed with $n=249$ people. The cases were determined according to the inclusion and exclusion criteria in the study and there was no data loss.

\section{Criteria for the Study}

Inclusion criteria: Those who were treated with peripheral venous catheters in pediatric clinic in the study were included in this study.

Exclusion criteria: The children who had an immune deficiency, who had severe circulatory disorders and dehydration, who received chemotherapy, who had central catheters, who had dibetes mellitus, who had blood inserted, who had total parenteral nutrition, who previously participated in this study, who catheter inserted in another unit and who did not want to participate in the study were excluded.

\section{Variables of Research}

Dependent variables: Duration of the PIVC in the vein and number of times the PIVC was inserted until discharge in pediatric patients.

Independent variables: Child's age, gender, catheter type and catheterized area of the child.

\section{Data Collection Forms}

The data were collected with the "Peripheral Venous Catheter Monitoring Form" and "Phlebitis Scale", which were prepared according to the literature.

Peripheral Venous Catheter Monitoring Form, includes the child's age, gender, disease type, number of days in hospital, catheter type, use of heparin cap, catheterization site, type of drug given from catheter, fluid intake, fluid delivery method, duration of catheter in vein, number of catheters inserted while in hospital, the reasons for catheter removal.

The Phlebitis Scale was developed by Schultze and Gallant (2006). The scale, which involves the rating stages of the related symptoms in the observation of the catheters in terms of possible risks and/or phlebitis in patients undergoing catheter, consists of 5 stages, which are; Stage 1, the stage in which symptoms like pain, redness, and edema, which are the symptoms of phlebitis, are absent. Level 2 is the stage when early symptoms of phlebitis are seen. In this stage, there is redness less than $2.5 \mathrm{~cm}$ around the catheter and pain appearing with palpation. Stage 3 is the middle stage of phlebitis. In this level, there are signs of redness bigger than $2.5 \mathrm{~cm}$ and between $2.5 \mathrm{~cm}$ and $5 \mathrm{~cm}$ around the intra venous region, pain that occurs with palpation in the area, and stiffness around it. Stage 4 is the stage of advanced phlebitis or initial thrombophlebitis. In this stage, there are $5 \mathrm{~cm}$ or more redness in the area, pain, and stiffness appearing with palpation in or around the area. Stage 5 is the advanced stage of thrombophlebitis. In this stage, there are $4^{\text {th }}$ stage phlebitis and purulent drainage findings. ${ }^{[21,22]}$

\section{Data Collection}

Observations were made in the patient room by the pediatric clinical nurse (GY) before drug/fluid administration through the catheter and shift changes (average; 5 times/day). In cases where fluid infusion is given through the catheter; observation frequency (average; 1 time/hour) varied according to the type and amount of fluid administered. During the observation, the PIVC site; It was evaluated in terms of phlebitis, infiltration, dislocation, and occlusion. If these complications developed, the patient was taken to the intervention room for PIVC removal and re-application of PIVC. The area of the catheter in the body, the color/number of the catheters, and the control of the catheter area in terms of phlebitis were evaluated and recorded in the Phlebitis Scale by making observations. In addition, the insertion and removal times of these catheters, the number of the hospitalization days of the child, the number of the catheter interventions from the hospitalization to the discharge, the age, gender, medical diagnosis of the children, and other information like the medication and fluid that were applied during this catheter were obtained from the patient file. Applications such as catheter insertion stages, selection of the insertion area, selection of the color/number of the catheter, drug and fluid application stages, were made within the routine practices of the pediatric service. Thus, the reliability of the study was provided. No additional applications that may affect the results of the study were made, and the study was conducted in the observational and descriptive fashion.

\section{Data Analysis}

The data were recorded and analyzed by using the SPSS 22 Software. The fitness of the data to normal distribution was tested. The quantitative data were expressed with mean and standard deviation (SD); and the qualitative data were expressed with numbers and percentages. For the comparison of the quantitative data between the groups, the significance test for the difference between two mean values and the Pearson Correlation Test was used. $\mathrm{p}<0.05$ was considered to be significant in statistical terms.

\section{Ethical Considerations}

The study was conducted in line with the principles of the Helsinki Declaration. The permission of the institution for the study and the approval of the Ethics Committee were obtained from the Tokat Gaziosmanpasa University Ethics Committee of Clinical Research (2017/6, 17-KAEK-052); and oral consents were obtained from the children/parents who met the inclusion criteria for the study.

\section{RESULTS}

It was determined that a total of $57.8 \%$ of the children who were included in the study were 1-36 months old, $60.6 \%$ were male, $90.8 \%$ were because of an acute illness, and $66.7 \%$ were hospitalized for more than 6 days. It was also found that the most frequently used catheter was the yellow/24 
number catheter (87.6\%), none of them had heparin valves, the most frequently used area was the area above the hand $(47.8 \%), 83.1 \%$ were given medicine, $51.8 \%$ were given fluid, and $62 \%$ of these were given fluid with infusion pump. It was determined that $13.3 \%$ of the catheters that were inserted to children remained in the vein for $2-24$ hours, $25.7 \%$ remained for $25-48$ hours, $30.1 \%$ remained for $49-72$ hours, $20.5 \%$ remained for $73-96$ hours and $10.4 \%$ remained for $97-144$ hours; and $73.5 \%$ of the catheters were removed because of the lack of the fluid/medicine flow (obstruction), $12.9 \%$ of the catheters were displaced, $4 \%$ were removed because of infiltration, $2 \%$ were removed because of phlebitis $\left(1^{\text {st }}\right.$ and $2^{\text {nd }}$ levels), and $7.6 \%$ were removed because of the termination of the treatment/discharge (Table 1).

\begin{tabular}{|c|c|c|}
\hline & Number & $\%$ \\
\hline \multicolumn{3}{|l|}{ Age } \\
\hline $\begin{array}{l}1-36 \text { month } \\
37 \text { month }-15 \text { years }\end{array}$ & $\begin{array}{l}144 \\
105\end{array}$ & $\begin{array}{l}57.8 \\
42.2\end{array}$ \\
\hline \multicolumn{3}{|l|}{ Gender } \\
\hline $\begin{array}{l}\text { Female } \\
\text { Male }\end{array}$ & $\begin{array}{c}98 \\
151\end{array}$ & $\begin{array}{l}39.4 \\
60.6\end{array}$ \\
\hline \multicolumn{3}{|l|}{ Disease type } \\
\hline $\begin{array}{l}\text { Acute illness } \\
\text { Acute and chronic illness }\end{array}$ & $\begin{array}{c}226 \\
23\end{array}$ & $\begin{array}{c}90.8 \\
9.2\end{array}$ \\
\hline \multicolumn{3}{|l|}{ Number of days in hospital } \\
\hline $\begin{array}{l}1-5 \text { days } \\
6 \text { days and }+\end{array}$ & $\begin{array}{c}83 \\
166\end{array}$ & $\begin{array}{l}33.3 \\
66.7\end{array}$ \\
\hline \multicolumn{3}{|l|}{ Catheter type } \\
\hline $\begin{array}{l}\text { Yellow/24 } \\
\text { Blue/22 }\end{array}$ & $\begin{array}{l}218 \\
31\end{array}$ & $\begin{array}{l}87.6 \\
12.4\end{array}$ \\
\hline \multicolumn{3}{|l|}{ Heparin valves } \\
\hline $\begin{array}{l}\text { Used } \\
\text { Not used }\end{array}$ & - & $\overline{100}$ \\
\hline \multicolumn{3}{|l|}{ Catheterized area } \\
\hline $\begin{array}{l}\text { Hand } \\
\text { Arm } \\
\text { Foot } \\
\text { Head }\end{array}$ & $\begin{array}{c}119 \\
88 \\
41 \\
1\end{array}$ & $\begin{array}{c}47.8 \\
35.3 \\
16.5 \\
0.4\end{array}$ \\
\hline \multicolumn{3}{|l|}{ Medicine administration status from catheter } \\
\hline $\begin{array}{l}\text { Antibiotic } \\
\text { Other } \\
\text { Did not take medicine }\end{array}$ & $\begin{array}{c}203 \\
4 \\
42\end{array}$ & $\begin{array}{c}81.5 \\
1.6 \\
16.9\end{array}$ \\
\hline \multicolumn{3}{|l|}{ Fluids administration status from catheter } \\
\hline $\begin{array}{l}\text { Took fluids } \\
\text { Did not take fluids }\end{array}$ & $\begin{array}{l}129 \\
120\end{array}$ & $\begin{array}{l}51.8 \\
48.2\end{array}$ \\
\hline \multicolumn{3}{|l|}{ Fluids application method* } \\
\hline $\begin{array}{l}\text { With infusion pump } \\
\text { With drop setting set }\end{array}$ & $\begin{array}{l}80 \\
49\end{array}$ & $\begin{array}{l}62.0 \\
38.0\end{array}$ \\
\hline \multicolumn{3}{|c|}{ Durations of peripheral venous catheters in veins } \\
\hline $\begin{array}{l}2-24 \text { hours } \\
25-48 \text { hours } \\
49-72 \text { hours } \\
73-96 \text { hours } \\
97-144 \text { hours }\end{array}$ & $\begin{array}{l}33 \\
64 \\
75 \\
51 \\
26\end{array}$ & $\begin{array}{l}13.3 \\
25.7 \\
30.1 \\
20.5 \\
10.4\end{array}$ \\
\hline \multicolumn{3}{|l|}{ Reasons for catheter removal } \\
\hline Lack of the fluid/medicine flow (obstruction) & 183 & 73.5 \\
\hline $\begin{array}{l}\text { Catheter dislocation } \\
\text { Infiltration }\end{array}$ & $\begin{array}{l}32 \\
10\end{array}$ & $\begin{array}{c}12.9 \\
4.0\end{array}$ \\
\hline Phlebitis & 5 & 2.0 \\
\hline Termination of the treatment/discharge & 19 & 7.6 \\
\hline
\end{tabular}

It was determined that the duration of the catheter in veins was $58.76 \pm 28$ hours, the catheter was inserted $3.61 \pm 1$ times during hospitalization. The duration of the catheter in the veins in children between 1-month-old-36-month-old $(55.62 \pm 25$ hours) was shorter than the children who were older than 37 months (63.06 \pm 30 hours); and the difference between the averages of these periods was statistically significant $(p<0.05)$. It was also determined that the number of catheters inserted from the hospitalization to discharge of the children who were 1-36 months old $(3.76 \pm 1)$ were higher than the children who were older than 37 months; however, there were no statistically significant differences between the groups ( $p>0.05)$. It was determined that the duration of the catheter in the vein and the number of catheters inserted from the hospitalization to discharge, according to the gender of the children, the area where the catheter was inserted, and the color/number of the catheter were not statistically significant $(p>0.05)$. It was determined that the catheters that were inserted in the foot/head vein $(52.98 \pm 27)$ were shorter hours than those that were inserted in the hand/arm area $(59.93 \pm 28)(p>0.05)$. In addition, it was also determined in terms of the color/number of the catheters that the duration of the yellow/24 catheters in the veins $(57.51 \pm 27)$ was shorter than the blue/22 catheters $(67.52 \pm 31)$, the number of the catheters inserted from the hospitalization to the discharge was higher ( $p>0.05$ ) (Table 2).

Table 2. According to some variables, the means of durations of PIVC in veins (hour), number of PIVC inserted from hospitalization to discharge

\begin{tabular}{lcc}
\hline Age & $\begin{array}{c}\text { Durations of PIVC } \\
\text { in veins (hour) }\end{array}$ & $\begin{array}{c}\text { Number of PIVC inserted } \\
\text { from hospitalization to } \\
\text { discharge }\end{array}$ \\
\hline $1-36$ month & Mean \pm SD & Mean \pm SD \\
37 month -15 years & $55.62 \pm 25.68$ & $3.76 \pm 1.71$ \\
$p$ & $63.06 \pm 30.65$ & $3.41 \pm 1.63$ \\
Gender & 0.039 & 0.112 \\
Female & $57.87 \pm 28.51$ & $3.52 \pm 1.53$ \\
Male & $59.33 \pm 27.85$ & $3.68 \pm 1.78$ \\
p & 0.689 & 0.461 \\
Catheter type & $57.51 \pm 27.46$ & $3.66 \pm 1.70$ \\
Yellow/24 & $67.52 \pm 31.0$ & $3.25 \pm 1.52$ \\
Blue/22 & 0.063 & 0.205 \\
p & & \\
Catheterized area & $59.93 \pm 28.01$ & $3.57 \pm 1.72$ \\
Hand-Arm & $52.98 \pm 27.95$ & $3.83 \pm 1.51$ \\
Foot-Head & 0.144 & 0.367 \\
p & $58.76 \pm 28.07$ & $3.61 \pm 1.68$ \\
\hline
\end{tabular}

Data are shown as mean \pm standard deviation. For the comparison of the quantitative data between the groups, the significance test for the difference between two mean values were used. $p<0.05$ was considered to be significant in statistical terms.

The poor negative correlation between "durations of PIVC in veins" and "number of PIVC inserted from hospitalization to discharge" was found to be statistically significant $(p<0.05)$ (Table 3). 


$\begin{aligned} & \text { Table 3. Correlation between durations of PIVC in veins (hour) and } \\
& \text { number of PIVC inserted from hospitalization to discharge ( } \mathrm{n}=249)\end{aligned}$
\begin{tabular}{lccc} 
& Mean \pm SD & p & r \\
\hline $\begin{array}{l}\text { Number of PIVC inserted from } \\
\text { hospitalization to discharge }\end{array}$ & $3.61 \pm 1.68$ & 0.014 & -0.156 \\
Durations of PIVC in veins (hour) & $58.76 \pm 28.07$ & & \\
\hline r: Pearson Correlation Test & & & \\
\hline
\end{tabular}

\section{DISCUSSION}

Vascular access devices are commonly inserted devices that facilitate the administration of fluids and drugs, as well as blood sampling. Despite their common use in clinical settings, these devices are prone to occlusion and failure, requiring replacement and exposing the patient to ongoing discomfort/ pain, local vessel inflammation and risk of infection. ${ }^{[1,3,23]}$ In order to prevent these complications, observation of the catheter area by nurses is very important, especially in irritant drug infusions. ${ }^{[20]}$ However, it was seen that studies conducted on catheter vein duration and frequency of interventions especially in children are in a limited number in the literature. It is difficult to find, follow up and care peripheral vessels, especially in infants and young children. In a study, it was determined that children who underwent PIVC mostly developed complications (67.7\%) below the age of 3 years. ${ }^{[24]}$ Since verbal and cognitive development in the 0-3 age group is not sufficient compared to the older age groups, cooperation is also difficult. Cognitive development accelerates in children over the age of 3 with the start of pre-school education. [5] For these reasons, in this study, a grouping was made as over 3 years old and under. As a primary result of the present study, it was determined that the peripheral venous catheter in children under three years of age had a shorter duration of remaining in the veins, and children were subjected to repeated peripheral venous catheter attempts because of obstructions before their treatments were completed (Table 1 and Table 2). In this study, the fact that there was a statistically significant decrease in the number of catheters inserted from the hospitalization to the discharge of the children as the duration of the peripheral venous catheters in the veins increased in the children who were included in the study is an important result at this point (Table $\mathbf{3}$ ).

These primary findings are an important result showing that hospitalized children are frequently exposed to catheter applications, which is one of the traumatic procedures. Repeated traumatic procedures can lead to pain, stress, problems in the child's psychosocial development, loss of labor and cost. It is an important issue for healthcare professionals to take measures against repeated invasive procedures and to increase such studies. ${ }^{[12,18,23]}$

Jeong et al. (2017) determined that the mean PIVC dwell time was 55.62 \pm 27 hours, mostly at 24-72 hours intervals, in 1596 pediatric patients. ${ }^{[20]}$ In another study conducted on children who were between the ages 3-18, it was found that the mean duration of catheterization was 83.53 hours. ${ }^{[25]}$ It is considered that the inclusion of children under 3 years of age in this study may have caused a lower catheterization time (58.76 \pm 28 hours). In this study, it was found that the catheter duration in the veins was shorter when yellow/24 number catheter was used especially in children under 36 months who had catheters inserted in the foot/head veins. In the period that passed from the hospitalization of the children to the discharge, the number of catheters was higher in children who were under 36 months, in those with catheters in the foot/head veins, and when yellow/24 number catheters were used. As the age decreases in children, so does the vascular lumen, and the catheter may be dislocated because of the natural movements of children and the lack of cooperation, which can cause infiltration and extravasation. It was also reported in studies that catheter insertion from lower extremity veins increased complication risk. ${ }^{[11,20,24]}$ In addition, it is also known that catheters that are commonly used in pediatric patients (yellow/24 number; $87.6 \%$ for this study) with smaller internal lumen have decreased stay is the veins in fluid and/or drug administration especially in case internal lumen is exposed to damage due to intense, acidic and irritant drugs. In the present study, antibiotics (81.5\%) were the most commonly used drug type. In addition, previous studies showed that antibiotics are a risk for phlebitis formation and other complications. ${ }^{[20,24]}$ In another study, it was found that the mean duration of the peripheral venous catheter in the veins of pediatric patients was $68.82 \pm 35$ hours, and the duration of remaining in the veins decreased due to similar risk factors. ${ }^{[10]}$ In a similar study, the rate of developing complications regarding peripheral venous catheter in pediatric patients was 49.7\%, $6 \%$ phlebitis developed and complications developed under 3 years of age at the highest rate as in this study. ${ }^{[24]}$ In the present study, it was found that the incidence of phlebitis was low (2\%) among the causes of catheter removal. In this study, the phlebitis rates being low may be associated with short catheter vein durations in children who were included in the study. Jacinto et al. ${ }^{[26]}$ (2014) aimed at a study to identify risk factors for phlebitis related to PIVC in children. Similarly, conducted the study with 338 children, nine (2.7\%) developed phlebitis. Laudenbach et al. ${ }^{[27]}$ (2014) conducted a study with 80 children between the ages of 2 and 17 and reported that $22.5 \%$ of the children developed peripheral intra venous catheterization complications, and the most common complications were obstruction and infiltration. Similarly, in the present study, it was also observed that obstruction was a major problem as a catheter complication (73.5\%).

The findings obtained in the study show that innovative studies must be conducted to solve the problem of designing the material (other variables; catheter type, heparinous valve, flushing, drug density, dilution, dressing, etc.) in the case of failure in fluid/drug flow given from the catheter (obstruction and catheter dislocation) to reduce the number of catheter interventions in children and to increase the duration of the catheter in veins before treatment end. ${ }^{[2,17,18,23,28]} \mathrm{A}$ study aimed at examining the effectiveness of IV House UltraDressing for protecting PIVCs in pediatric patients was conducted. This randomized controlled trial comprised 60 pediatric patients 
(aged 2-24 months): 30 in the experimental group and 30 in the control group. IV House UltraDressing has been determined to be a useful device that can be used in pediatric patients to increase catheter waiting time and to protect and stabilize PIVCs. ${ }^{[18]}$ To protect and stabilize PIVCs is an important nursing care. Because, as mentioned above, it is difficult and traumatic to find the right vascular pathway in children. The reasons for the difficulty in inserting catheters in pediatric patients are associated with the adipose tissue being more, the veins being small, and the cooperation being insufficient. For this reason, it must be the main target to ensure that the catheters that are inserted in children with difficulty remain in the vein for a long time unless clinical indications develop. ${ }^{[4,8]}$ Because decreasing the traumatic procedures that are associated with pain in children is an approach intended for the philosophy of atraumatic care. For this reason, it is recommended that innovative and experimental studies are conducted to increase the duration of the catheter in the veins of children and to reflect these findings to the literature and pediatric clinics. The scientific developments and practices regarding this procedure, which is the responsibility of nurses, must be closely followed, and new knowledge and skills must be transferred to practice.

\section{Limitations}

The study was conducted in the Pediatric Clinic of a University Hospital. For this reason, the data were limited to the children in this clinic and cannot be generalized to all clinics. This research is limited by some variables shown in this study that can affect the length of time the catheter remains in the vein.

\section{ETHICAL DECLARATIONS}

Ethics Committee Approval:The permission of the institution for the study and the approval of the Ethics Committee were obtained from the Ethics Committee of Clinical Research (2017/6, 17-KAEK-052)

Informed Consent: All patients signed the free and informed consent form.

Referee Evaluation Process: Externally peer-reviewed.

Conflict of Interest Statement: The author(s) declared no potential conflicts of interest with respect to the research, authorship, and/or publication of this article.

Financial Disclosure: The authors declared that this study has received no financial support.

Author Contributions: All of the authors declare that they have all participated in the design, execution, and analysis of the paper, and that they have approved the final version.

Acknowledgements: We would like to thank Nurse Şifa Özay, Nurse Tülin Kayalaçin, Nurse Burcu Aras and other nurses, children and their mothers, who contributed to the data collection step of the present study.

Note: This research is presented as oral presentation at the 2 . International 7. National Congress of Pediatric Nursing (2019 year-Turkey-Izmir)

\section{REFERENCES}

1. Alexandrou E. Ray-Barruel G. Frost S, et al. Prevalence of the Use of PIVCs. J Hosp Med 2015;8:530-3.

2. Alexandrou E, Ray-Barruel G, Carr PJ, et al. Use of short peripheral intra venous catheters: characteristics, management, and outcomes worldwide. J Hosp Med 2018;13(5):1-7.

3. Keogh S, Flynn J, Marsh N, Higgins N, Davies K, Rickard CM. Nursing and midwifery practice for maintenance of vascular access device patency. $A$ cross-sectional survey. Int J Nurs Stud 2015;52(11):1678-85.

4. Rickard CM, Marsh N, Webster J et al. Dressings and securements for the prevention of peripheral intra venous catheter failure in adults (SAVE): a pragmatic, randomised controlled, superiority trial. Lancet 2018;392(10145):419-30.

5. Çavuşoğlu H. Çocuk Sağlığı Hemşireliği. Sistem Ofset Basımevi; Ankara: 2019.

6. Cihan Erdoğan B, Denat Y. Phlebitis that is among peripheric intra venous catheter complications and the nursing care. J Hum Rhythm 2016;2(1):612.

7. O'grady NP, Alexander M, Burns LA et al. Guidelines for the prevention of intra vascular catheter-related infections. Clin Infect Dis 2011;52(9):16293.

8. Webster J, Osborne S, Rickard CM, New K. Clinically-indicated replacement versus routine replacement of peripheral venous catheters. Cochrane Database Syst Rev. 2015;(8):CD007798.

9. Rickard CM, Webster J, Wallis MC et al. Routine versus clinically indicated replacement of peripheral intra venous catheters: a randomised controlled equivalence trial. Lancet 2012;380(9847):1066-74.

10. Abdelaziz RB, Hafsi H, Hajji $\mathrm{H}$ et al. Peripheral venous catheter complications in children: predisposing factors in a multicenter prospective cohort study. BMC Pediatrics 2017;17(1):208.

11. Suliman M, Saleh W, Al-shiekh H, Taan W, AlBashtawy M. The incidence of peripheral intra venous catheter phlebitis and risk factors among pediatric patients. J Pediatr Nurs 2020;50:89-93.

12. Kassab M, Alhassan AA, Alzoubi KH, Khader YS. Number and frequency of routinely applied painful procedures in University Neonatal Intensive Care Unit. Clin Nurs Res 2019;28(4):488-501.

13. Wu Z, McGoogan JM. Characteristics of and important lessons from the coronavirus disease 2019 (COVID-19) outbreak in China: summary of a report of 72314 cases from the Chinese Center for Disease Control and Prevention. JAMA 2020;323(13):1239-42.

14. Bai $Y$, Yao L, Wei T et al. Presumed asymptomatic carrier transmission of COVID-19. JAMA 2020;323(14):1406-7.

15. Indarwati F, Mathew S, Munday J, Keogh S. Incidence of peripheral intra venous catheter failure and complications in paediatric patients: Systematic review and meta analysis. Int J Nurs Stud 2019;102:103488.

16. Kahraman A, Özalp Gerçeker G, Yardımcı F et al. The effect of a nurse education program on Infiltration and extravasation in pediatric patients at a university hospital. J Pediatr Res 2020;7(4):309-15.

17. Lv L, Zhang J. The incidence and risk of infusion phlebitis with peripheral intra venous catheters: A meta-analysis. J Vasc Access 2020;21(3):342-9.

18. Büyükyılmaz F, Şahiner NC, Cağlar S, Eren H. Effectiveness of an intra venous protection device in pediatric patients on catheter dwell time and phlebitis score. Asian Nurs Res 2019;13(4):236-41.

19. Törüner E, Büyükgönenç L. Çocuk Sağlığı Temel Hemşirelik Yaklaşımları. Nobel Tıp Kitapevleri: Ankara; 2017.

20. Jeong IS, Jeon GR, Lee MS et al. Intra venous infiltration risk by catheter dwell time among hospitalized children. J Pediatr Nurs 2017;32:47-51.

21. Gallant P, Schultz A. Evaluation of a visual infusion phlebitis scale for determining appropriated is continuation of peripheral intra venous catheters. J Infus Nurs 2006;29(6):338-45.

22. Kuş B, Büyükyılmaz B. Visual infusion phlebitis assessment scale: study of independent inter-observer compliance. Florence Nightingale J Nurs 2018;26(3):179-86. 
23. Hawthorn A, Bulmer AC, Mosawy S, Keogh S. Implications for maintaining vascular access device patency and performance: Application of science to practice. J Vasc Access 2019;20(5):461-70.

24. Abusafia BM, Boztepe H. Evaluation of Peripheral Intravenous CatheterInduced Local Complications in Pediatrics. J Clin Nurs. 2017;10.1111/ jocn.13730.

25. Olgun S, Demiray A, Eşer I, Khorshid L. Phlebitis and infiltration status in peripheral intra venous catheterisation in children. J Ege University Nursing Faculty 2014;30(2):40-54.

26. Jacinto, AKDL, Avelar AFM, Wilson AMMM, Pedreira MDLG. Phlebitis associated with peripheral intra venous catheters in children: study of predisposing factors. Escola Anna Nery 2014;18(2):220-6.

27. Laudenbach N, Braun C, Klaverkamp L, Hedman-Dennis S. Peripheral IV stabilization and the rate of complications in children: An exploratory study. J Pediatr Nurs 2014;29:348-53.

28. Lim EYP, Wong CYW, Kek LK, Suhairi SSBM, Yip WK. Improving the visibility of intra venous (IV) site in pediatric patients to reduce IV site related complications-An evidence-based utilization project. J Pediatr Nurs 2018;41:39-45. 